\title{
Penguatan Gender Dalam Pembelajaran Humanis
}

\author{
Munawarah \\ Institut Agama Islam Negeri (IAIN) Bone
}

\begin{abstract}
Gender strengthening in the education process requires a structured effort that must begin by appreciating the inherent gender aspects of each community, both masculine and feminism. In this context, humanist education is an educational model that has a gender strengthening dimension.
\end{abstract}

Keywords: Gender Strengthening, Humanist Education

\section{Pendahuluan}

Pendidikan humanis telah menjadi suatu paradigma pendidikan yang mendudukkan manusia pada posisi fitrahnya sebagai makhluk pedagogik yang dalam hal dapat dipahami bahwa manusia merupakan makhluk yang dapat dididik sekaligus mendidik dengan segala potensi yang dimilikinya. Dalam konteks tersebut, pendidikan harus dikembalikan pada fungsi dasarnya sebagai wahana pencerdasan peserta didik dengan memberikan akses yang luas pada mereka untuk terlibat aktif dalam kegiatan pembelajaran. Menyikapi hal tersebut, Zamroni mengemukakan bahwa proses pendidikan seyogyanya mendudukan pendidik dan peserta didik sebagai mitra belajar sehingga peserta didik dalam lebih aktif mengembangkan kreativitas belajarnya. Hal ini secara tidak langsung mereduksi pola pendidikan yang cenderung mendudukkan pendidik sebagai pihak yang selalu benar dan tidak boleh dikritisi. ${ }^{37}$

Menggambarkan fenomena empiris yang dialami oleh dunia pendidikan dewasa ini dalam konteks keindonesiaan, K. Sihontang mengemukakan bahwa problema yang dihadapi dunia pendidikan di Indonesia saat ini adalah, 1) proses belajar mengajar yang berlangsung secara mekanis dimana peserta didik cenderung diperlakukan laksana mesin, dimana proses kehidupan mereka lebih banyak tergantung dari luar dirinya, anak didik dipandang laksana botol kosong, tanpa melihat kemampuan dan potensi yang dimilikinya, sehingga dalam proses

\footnotetext{
${ }^{37}$ Zamroni, Pendidikan untuk Demokrasi: Tantangan menuju Civil Society, (Yogyakarta: Bigraf Publishing, 2001), h. 45
} 
belajar mengajar berjalan dengan sangat ketat dan pendidik memandang dirinya sebagai satusatunya informasi dan pengetahuan, 2) akibat yang muncul dari proses belajar secara mekanistik, proses belajar mengajar berjalan secara monolog dan terjadi hubungan searah sehingga peserta didik bersikap pasif terhadap materi yang diberika, 3) walaupun pada dasarnya tujuan pendidikan adalah untuk mengembangkan semua potensi yang dimiliki peserta didik, namun dalam kenyataanya proses belajar mengajar yang terjadi saat ini lebih menekankan pada satu aspek yaitu aspek kognitif. Kondisi ini membuat peserta didik tidak mempunyai kesempatan untuk mengembangkan potensi dan dimensi kemanusiaan yang lain yakni, aspek afektif, sosial dan psikomotorik, 4) isi kurikulum yang sangat berat dan padat dan tidak disesuaikan dengan kebutuhan peserta didik, sehingga mereka bersikap negatif, pesimis, tidak mempunyai motivasi terhadap materi yang diberikan. ${ }^{38}$

Apa yang digambarkan oleh Zamrono dan K. Sitohang tersebut, pada dasarnya, merupakan suatu cita-cita ideal pendidikan yang dibenturkan dengan realitas empiris sehingga menunjukkan kesenjangan das sein dan das sollen dalam penjabaran amanah konstitusi pada konteks pendidikan di Indonesia. Hal ini sesuai dengan tujuan pendidikan yang termaktub dalam Undang-Undang Sistem Pendidikan Nasional Nomor 20 Tahun 2003 yaitu:

Tujuan Pendidikan Nasional adalah mengembangkan kemampuan dan membentuk watak serta peradaban bangsa yang bermartabat dalam rangka mencerdaskan kehidupan bangsa, bertujuan untuk berkembangnya potensi peserta didik agar menjadi manusia yang beriman dan bertakwa kepada Tuhan Yang Maha Esa, berakhlak mulia, sehat, berilmu, cakap, kreatif, mandiri, dan menjadi warga negara yang demokratis serta bertanggung jawab. ${ }^{39}$

Dunia pendidikan kita saat ini tengah mengalami krisis yang cukup serius. Krisis ini tidak saja disebabkan oleh anggaran pemerintah yang sangat rendah untuk membiayai kebutuhan vital dunia pendidikan kita, tetapi juga lemahnya tenaga ahli, visi serta politik pendidikan nasional yang tidak jelas. Hal ini secara tidak langsung pada proses penjabaran pendidikan di sekolahsekolah sehingga pembelajaran humanis menjadi sulit untk diwujudkan. Bisa dibayangkan apabila pendidik kurang mendapatkan keadilan maka hal ini secara tidak lamgsung berimplikasi

\footnotetext{
${ }^{38}$ K. Sihontang, Paradigma Humanistk dalam Pendidikan, Jurnal Basis Vol.5 No.1.2002, h. 34.

39 Republik Indonesia, Undang-Undang Sistem Pendidikan Nasional Nomor 20 Tahun 2003, https://salamadian.com. (15 Juni 2018)
} 
pada komitmen yang dimilikinya untuk mewujudkan pembelajaran yang mampu mengakselerasi potensi peserta didik sebagai individu yang memiliki sisi humanis.

\section{Konsep Gender dan Relevansinya dengan Pendidikan}

Dalam kerangka etimologisnya, gender merupakan kata bahasa Inggris yang mengarah pada arti jenis kelamin. ${ }^{40}$ Dalam kerangka terminologisnya, gender digambarkan oleh Nasaruddin Umar dengan mengutip apa yang digambarkan oleh H.T. Wilson bahwa gender dapat dipahami sebagai suatu dasar untuk menentukan perbedaan sumbangan laki-laki dan perempuan pada kebudayaan dan kehidupan kolektif yang sebagai akibatnya mereka menjadi laki-laki dan perempuan. Sementara menurut Elaine Showalter, masih dalam kutipan Nasaruddin Umar, gender lebih dari sekedar pembedaan laki-laki dan perempuan dilihat dari konstruksi sosial budaya. Ia lebih menekankan gender sebagai konsep analisis yang dapat digunakan untuk menjelaskan sesuatu. ${ }^{41}$

Gender merupakan suatu konsep yang mengarah pada upaya untuk melihat realitas yang melekat pada sisi maskulinitas seorang laki-laki serta sisi feminitas seorang perempuan. Tidak bisa dipungkiri bahwa laki-laki dan perempuan diciptakan dengan identitas masing-masing yang pada gilirannya berimplikasi pada fungsi-fungsi sosialnya. Menyikapi hal tersebut, Mansour Fakih mengemukakan bahwa perbedaan gender sebenarnya tidak menjadi masalah sepanjang tidak melahirkan ketidakadilan gender. Masalah itu akan muncul ketika perbedaan gender telah melahirkan berbagai ketidakadilan, terutama bagi kaum perempuan. Untuk memahami bagaimana keadilan gender menyebabkan ketidakadilangender perlu dilihat manifestasi ketidakadilan dalam berbagai bentuknya, seperti marginalisasi atau proses pemiskinan ekonomi, subordinasi atau anggapan tidak penting dalam keputusan politik, pembentukan stereotipe atau melalui pelabelan negatif, kekerasan (violence), beban kerja lebih panjang dan lebih lama (burden), serta sosialisasi ideologi nilai peran gender. ${ }^{42}$

\footnotetext{
${ }^{40}$ John Echols dan Hasan Shadily, Kamus Inggris-Indonesia, (Jakarta: Gramedia, 1983), h. 265

${ }^{41}$ Nasaruddin Umar, Argumen Kesetaraan Gender Perspektif al-Q ur'an, (Jakarta: paramadina, 1999), h. 33-34

${ }^{42}$ Mansour Fakih, Analisis Gender dan Transformasi Sosial, (Yogyakarta: Pustaka Pelajar, 1997), h. 13
} 
Studi yang dilakukan Nasaruddin Umar terhadap al-Quran menunjukkan adanya kesetaraan gender. Dia menemukan lima variabel yang mendukung pendapatnya, yakni, 1) Lakilaki dan perempuan sama-sama sebagai hamba. Hal ini bisa dilihat misalnya dalam surat alHujurat (49): 13 dan al-Nahl (16): 97; (2) Laki-laki dan perempuan sebagai khalifah di bumi. Hal ini terlihat dalam surat al-Baqarah, 2): 30 dan al-An'am (6): 165, 3) Laki-laki dan perempuan menerima perjanjian primordial seperti terlihat dalam surat al-A'raf (7): 172, 4) Adam dan awa terlibat secara aktif dalam drama kosmis. Kejelasan ini terlihat dalam surat al-Baqarah (2): 35 dan 187, al-A'raf (7): 20, 22, dan 23.; dan 5) Laki-laki dan perempuan berpotensi meraih prestasi seperti yang terlihat dalam surat Ali 'Imran (3): 195, al-Nisa' (4): 124, al-Nahl (16): 97, dan Ghafir (40): $40 .{ }^{43}$

Berbagai ayat al-Qur'an yang menggambarkan gender tersebut telah memberikan dimensi pendidikan terkait bagaimana gender tidak semestinya dijadikan sebagai alasan untuk mendudukkan perempuan sebagai komunitas yang tidak mendapatkan hak-hak asasinya sebagai individu yang merdeka. Banyaknya faktor empiris yang mendudukkan perempuan sebagai komunitas yang tertindas dalam dunia pendidikan.

Kalaupun kemudian muncul pendapat yang bernada misoginis terhadap perempuan, atau yang menunjukkan subordinasi perempuan dan superioritas laki-laki, dikarenakan adanya bias gender dalam pemahaman atau penafsiran teks-teks al-Quran. Adapun penyebab terjadinya bias gender ini menurut Nasaruddin bisa ditelusuri dalamsepuluh faktor, yakni (1) Pembakuan tanda huruf, tanda baca, dan qiraat; (2) Pengertian kosa kata (mufradat); (3) Penetapan rujukan kata ganti (dlamir); (4) Penetapan batas pengecualian (istisna'); (5)Penetapan arti huruf 'athaf; (6) Bias dalam struktur bahasa; (7) Bias dalam kamus bahasa Arab; (8) Bias dalam metode tafsir; (9) Pengaruh riwayat Isra'iliyat; dan (10) Bias dalam pembukuan dan pembakuan kitab-kitab fikih. ${ }^{44}$ Pendidikan Humanis sebagai Kerangka Penguatan Gender

Pendidikan humanis merupakan suatu paradigma pendidikan yang berkaitan erat dengan upaya untuk memberikan penguatan pada gender sebagai suatu isu penyamaan posisi laki-laki dan perempuan dalam strata sosial. Secara fitrah, manusia memiliki kesamaan tanpa harus

\footnotetext{
${ }^{43}$ Nasaruddin Umar, Argumen Kesetaraan Gender Perspektif al-Qur'an, 248-265

${ }^{44}$ Nasaruddin Umar, Argumen Kesetaraan Gender Perspektif al-Q ur'an, 268-299
} 
dibedakan atas nama jenis kelamin. Dalam menguatkan posisi pendidikan humanis sebagai kerangka penguatan gender, Lorenz Bagus menggambarkan bahwa kata humanis paling tidak dapat digambarkan sebagai salah satu karakteristik yang dimiliki oleh aliran dalam filsafat yang bertujuan menghidupkan rasa kemanusiaan dengan pergaulan yang lebih menghargai sisi kemanusiaan itu sendiri. ${ }^{45}$

Ilustrasi di atas pada dasarnya mengarah pada konsep pendidikan humanis yang berupaya mengembangkan kesadaran manusia akan sisi kemanusiaannya. Hal ini telah dipertegas oleh Paulo Freire yang menyatakan bahwa tujuan pendidikan humanis adalah untuk mencari ilmu pengetahuan guna memenuhi hasrat dan keinginan peserta didik dan guru dengan kesadaran untuk menciptakan ilmu pengetahuan baru. ${ }^{46}$ Apa yang digambarkan oleh Paulo Freire ini menunjukkan bahwa manusia harus menyadari bahwa dirinya adalah ciptaan Tuhan yang telah dibekali dengan berbagai macam potensi untuk dapat berkembang sebagai individu ataupun sebagai makhluk sosial.

Pendidikan menurutnya adalah suatu upaya untuk pembebasan dan pemanusiaan. Dalam rangka pemanusiaan dan pembebasan itulah, Freire melihat penyadaran (conscientizacao) sebagai inti pendidikan. Conscientizacao adalah proses di mana manusia mendapatkan kesadaran yang terus semakin mendalam tentang realitas kultural yang melingkupi hidupnya dan akan kemampuannya untuk merubah realitas. Sebuah proses penyadaran yang mengarah sekaligus memproduksi suatu konsep pembebasan yang dinamis agar tercipta iklim kemanusiaan yang lebih utuh. Freire menerangkan conscientizacao sebagai proses menjadi manusia yang lebih penuh atau suatu proses perkembangan kesadaran melalui tiga tahap yang berbeda tapi saling berhubungan, yaitu magis, naïf, dan kesadaran kritis. ${ }^{47}$

Dalam konteks ini, pendidikan humanis menjadi sebuah model pendidikan yang mendudukkan perempuan sebagai komunitas yang perlu dihargai tanpa adanya perbedaan atas nama jenis kelamin yang angat subyektif. Muhammad Yusuf dengan mengutip pandangan

\footnotetext{
${ }^{45}$ Lorens Bagus, Kamus Filsafat, (Jakarta: Gramedia Pustaka Utama, 1996), h. 295

${ }^{46}$ Paulo Freire, Pendidikan Kaum Tertindas, (Yogyakarta: LP3ES, 1972), h. 190

${ }^{47}$ William A. Smith, Conscientizacao: Tujuan Pendidikan Paulo Freire, (Yogyakarta: Pustaka Pelajar, 2001), h. 15
} 


\section{An-Nisa', Volume XI Nomor 2 Desember 2018}

Arthur W. Comb mengemukakan bahwa ada lima faktor penghambat upaya untuk mengakselerasi sisi kemanusiaan seseorang yang dalam hal ini adalah:

1. Terbatasnya kesempatan

Pengembangan potensi yang dimiliki anak akan berkembang lebih aktif dan baik apabila kesempatan diberikan secara luas untuk menggunakan potensinya. Potensi yang dimiliki anak didik akan berkembang dengan baik apabila diberi stimulus dari lingkungannya dan mereka menggunakannya sesuai tahap perkembangan anak didik

2. Keterbatasan kebutuhan manusia

Membatasi anak dalam mengekspresikan dan mengaktualisasikan dirinya dapat mematikan potensi yang dimilikinya sehingga akan menimbulkan perasaan benci, jenuh belajar, dan jauh dari keluarga. Sebaliknya memberikan perhatian sepenuhnya dalam usaha mengembangkan potensi anak akan melahirkan anak cerdas dan mampu menyesuaikan diri, lebih stabil dan mudah meraih yang dicita-citakan.

\section{Konsep diri}

Konsep diri adalah pandangan diri tentang diri sendiri. Dalam hal ini konsep diri memiliki tiga dimensi diantaranya; Pertama, pengetahuan tentang diri sendiri. Pengetahuan ini meliputi apa yang diketahui tentang diri sendiri, seperti usia, jenis kelamin, bakat, minat, dan kemampuan. Kedua, harapan diri merupakan diri ideal. Ketiga, penilaian tentang diri. Anak didik yang mempunyai konsep diri negative akan memiliki pandangan negative pula terhadap dirinya. Dalam kondisi seperti ini akan membuat anak kurang realistis dan tidak stabil. Anak tersebut tidak mengetahui siapa dirinya sebenarnya (kekuatan dan kelemahannya) dan kaku dalam memandang suatu masalah. Hal ini dapat mempengaruhi dan merugikan anak itu sendiri, seperti gagal dalam mencapai cita-citanya.

4. Tantangan dan ancaman

Tantangan dan ancaman merupakan salah satu faktor yang dapat mempengaruhi pertumbuhan dan perkembangan potensi anak, seperti ketika seorang anak didik mengeluarkan kata-kata yang tidak pantas terhadap gurunya, maka secara psikologis perhatian anak akan terfokus pada sesuatu yang mengancam dirinya dan ia mengabaikan yang lain. Kondisi ini akan membatasi persepsi anak tentang lingkungannya. Hal ini mengarahkan kemampuannya untuk 
mempertahankan posisi ketika menghadapi suatu ancaman. Pada dasarnya anak didik akan merasakan hadirnya suatu tantangan bila dihadapkan padasuatu masalah yang menarik dan memiliki kesempatan untuk meraih kesuksesan. Dan ancaman akan timbul bila anak merasa tidak mampu menangani suatu permasalahan yang dihadapinya

5. Keterbatasan fisiologi

Kondisi fisiologi yang baik merupakan faktor pertama dan utama anak didik dalam usaha berinteraksi dan mengeksplorasi lingkungan dan alam sekitarnya. Kondisi fisiologi utama bagi anak didik adalah kesehatan, karena hal ini sangat penting bagi perkembangan dan pertumbuhan fisik serta perkembangan emosional anak. Adanya kekurangan gizi merupakan faktor yang menghambat perkembangan dan pertumbuhan anak didik yang menyebabkan terganggunya aktivitas. Kekurangan gizi bagi anak akan menyebabkan mudah terserang penyakit, malas, letih, kurang bersemangat. ${ }^{48}$

Berbagai hambatan tersebut harus dihadapi dengan memberikan penguatan gender dalam proses pendidikan yang humanis. Upaya ini tentunya merupakan suatu proses yang membutuhkan kebersamaan dari semua komponen yang terlibat pada proses pendidikan.

\section{Kesimpulan}

Berdasarkan uraian di atas, dapat dipahami bahwa penguatan gender pada proses pendidikan membutuhkan suatu upaya terstruktur yang harus dimulai dengan memberikan apresiasi terhadap sisi gender yang melekat pada masing-masing komunitas, baik maskulin ataupun feminism. Dalam konteks tersebut, pendidikan humanis menjadi sebuah model pendidikan yang memiliki dimensi penguatan gender tersebut.

\section{Daftar Pustaka}

Bagus, Lorens, Kamus Filsafat, Jakarta: Gramedia Pustaka Utama, 1996.

Echols, John dan Hasan Shadily, Kamus Inggris-Indonesia, Jakarta: Gramedia, 1983.

Fakih, Mansour, Analisis Gender dan Transformasi Sosial, Yogyakarta: Pustaka Pelajar, 1997.

Freire, Paulo, Pendidikan Kaum Tertindas, Yogyakarta: LP3ES, 1972.

\footnotetext{
${ }^{48}$ Muhammad Yusuf, Pendidikan Humanis dan Aplikasinya pada Pendidikan Islam: Telaah atas Pemikiran Abdul Munir Mulkhan, (Yogyakarta: UIN Sunan Kalijaga, 2007), h. 14-17
} 


\section{An-Nisa', Volume XI Nomor 2 Desember 2018}

Republik Indonesia, Undang-Undang Sistem Pendidikan Nasional Nomor 20 Tahun 2003, https://salamadian.com. (15 Juni 2018)

Sihontang, K., Paradigma Humanistk dalam Pendidikan, Jurnal Basis Vol.5 No.1.2002.

Smith, William A., Conscientizacao: Tujuan Pendidikan Paulo Freire, Yogyakarta: Pustaka Pelajar, 2001.

Umar, Nasaruddin, Argumen Kesetaraan Gender Perspektif al-Qur'an, Jakarta: paramadina, 1999.

Yusuf, Muhammad, Pendidikan Humanis dan Aplikasinya pada Pendidikan Islam: Telaah atas Pemikiran Abdul Munir Mulkhan, Yogyakarta: UIN Sunan Kalijaga, 2007.

Zamroni, Pendidikan untuk Demokrasi: Tantangan menuju Civil Society, Yogyakarta: Bigraf Publishing, 2001. 